\title{
Evaluating the Possibility of a Water Trading Scenario Coupled With Water Use Restriction in the Texas Southern High Plains
}

\author{
Kishor P Luitel (Corresponding author) \\ Department of Agricultural and Applied Economics, Texas Tech University \\ PO Box, Lubbock, Texas, USA
}

Tel: 1-806-742-2821_E-mail: kishor.luitel@ttu.edu

Rachna Tewari

Department of Agriculture, Geosciences, and Natural Resources

University of Tennessee Martin 265 Brehm Hall, Martin, Tennessee-38237, United States

Tel: 1-731-881-7196_E-mail: rtewari@utm.edu

\begin{abstract}
Donna M Mitchell
Department of Agricultural and Applied Economics, Texas Tech University

PO Box, Lubbock, Texas, USA
\end{abstract}

Tel: 1-806-742-2821_E-mail: donna.m.mitchell@ttu.edu

Aaron Benson

Zions Bancorporation

10 S. Main Street, Salt Lake City, Utah, USA

Phil Johnson

Department of Agricultural and Applied Economics, Texas Tech University

PO Box, Lubbock, Texas, USA

Tel: 1-806-742-2821 E-mail: phil.johnson@ttu.edu 
Received: April 7, 2015 Accepted: April 20, 2015

doi:10.5296/emsd.v4i1.7391

URL: http://dx.doi.org/10.5296/emsd.v4i1.7391

\begin{abstract}
Producers in the Texas Southern High Plains face the depletion of the Ogallala aquifer as groundwater withdrawals for irrigation have far exceeded recharge. Policy makers and stakeholders have been analysing various options in order to maintain adequate groundwater stock in the aquifer for future use. This study evaluated the possibility of implementing a water trading scenario coupled with water use restriction in the Texas Southern High Plains. The objective of this study was to examine the water use behaviour of agricultural producers and estimate the limits for the permit price and penalty for violation (when water use exceeds the restriction limit) for a water trading scenario in conjunction with water use restriction. This was accomplished using a non-linear dynamic optimization model for a planning horizon of 50 years. The results suggested that the decision of producers to engage in water trading introduced under a restricted management plan will be impacted by initial water levels in the aquifer, as well as the viability of pumping water when moving further into the planning horizon. The highest change in consumer surplus, price of permit, as well as the penalty of violation was observed in the periods where water becomes limiting and the overall supply of available water declines. It is evident that while management policies such as restricting water use and permitting water trading will have a definitive impact on the regional agricultural economy, they could still serve as useful tools to promote long term conservation of groundwater resources in the region.
\end{abstract}

Keywords: Ogallala aquifer, Water trading, Water use restriction, Texas High Plains

\title{
1. Introduction
}

Groundwater levels in the Ogallala Aquifer have witnessed a declining trend over the last fifty years. Producers in the Texas Southern High Plains face the depletion of this indispensable source of groundwater as withdrawals for irrigation have far exceeded recharge. Policy makers and stakeholders have been studying and analysing various options in order to maintain adequate groundwater stock in the aquifer for future use. Through survey among the stakeholders, several water conservation policies have been evaluated for the region (Amosson et al. 2009). Water use restriction is one of the policies under consideration in which the policy is a mandatory annual or multi-year limit that reduces the amount of water pumped from the Ogallala Aquifer for irrigation purposes with an objective to sustain water for future use (Amosson et al. 2009). In this direction, the High Plains Underground Water Conservation District No. 1 adopted a 50/50 Management Goal with an objective of retaining $50 \%$ of the current saturated thickness of the Ogallala aquifer in the next 50 years. To achieve this management goal, the District implemented rules that restrict annual pumping to 1.75 acre feet per contiguous acre for 2012 and 2013; 1.5 acre feet for 2014 and 2015; and 1.25 acre feet starting in 2016 (Postel, 2012). Given the above restriction being implemented in the Texas High Plains, water use becomes an important decision in irrigated agricultural 
production. Based on this background, this study proposes to explore the possibility of implementing a future groundwater trading scenario (coupled with water use restriction) among the agricultural producers in the Texas Southern High Plains.

\section{Review of Literature}

This section explores the existing literature on water trading market for groundwater, and creates a background for the study in hand. One concept of water trading is cap and trade system in general and its application to the natural resource markets, and then explores existing research that proposes cap and trade systems for groundwater management. A cap and trade policy is commonly intended to deter environmental pollutants (mostly industrial) such as carbon monoxide and sulphur dioxide in the air. In the past, this has been generally suggested in a national context, where the idea is to set a cap on the amount of emissions that can be released for the entire nation, and issue free or auctioned permits to entities that contribute to these emissions. Over time, the cap is reduced to lower the permissible levels of pollutants in the environment. The overarching goal is to reduce the cost of meeting an environmental objective, or increase the benefits from using a limited resource, by allowing the allocated property rights to move to where they are most valuable (Tietenberg, 1990; Kolstad, 2000).

The cap and trade model has also been applied to water quality and there are about 57 water quality trading pilot programs worldwide and among them 27 are active (Selman et.al, 2009). The cap and trade programs for water quality also operate on a similar premise of determining the cap on pollutants, and the number of permits available to industries based on the amount of pollution in wastewater. In addition, cap and trade systems have been also applied for groundwater credit trading in areas like the Edwards Aquifer in Texas, where streams are fed largely by groundwater (Chopra et al., 2005). Once surface waters are fully allocated, additional groundwater withdrawals may have adverse impacts on stream flow, and therefore a limit is placed on the total groundwater withdrawals in order to deter further impairment of surface water flows (Chopra et al., 2005). Cap and trade programs have also been suggested by researchers, political groups, and policy makers across the globe for regulating groundwater, however they have rarely been implemented so far as a groundwater management tool (Colby, 2000).

The most relevant study for enunciating the possibility of implementing a cap and trade system for groundwater by Thompson et al. (2009), clearly suggests the absence of previous empirical work on the marketing of capped groundwater supplies. This study also supports the fact that cap and trade groundwater management programs are a new concept that is just now emerging in the policy arena (Thompson et al., 2009). Thompson et al. study objective was to evaluate the merits of a cap and trade policy for the Republican Basin in Nebraska, an area characterized by high irrigation water consumption. They considered the effect of trades on the proportion of pumped water that is consumed, and the effect of reduced pumping on economic returns. The idea was to determine if cap and trade is an economically efficient alternative of reducing irrigation consumptive use. The results from this study conclude that the impact of a water market to trade groundwater allocations is influenced by the size of the 


\section{Macrothink}

allocation and on the characteristics of the land and irrigation systems involved. It was found that potential economic benefits from trade ranged from US $\$ 0$ to US $\$ 120$ per 1,000 cubic meters traded, from US $\$ 25$ to US $\$ 250$ per 1,000 cubic meters of reduction in consumptive use, and from US\$16 to US\$50 per hectare of irrigated land in the region (Thompson et al., 2009). The gains from trade would be split between buyers and sellers based on the negotiated selling price, and the highest values were found to occur at relatively high allocations, where withdrawals were capped at $65-75 \%$ of the expected unrestricted pumping level (Thompson et al., 2009).

The overall objective of this study is to examine the water use behaviour of agricultural producers and estimate the limits for the permit price and penalty for violation (when water use exceeds the restriction) for a water trading scenario in conjunction with water use restriction. This will be accomplished through two specific tasks:

1. Using a non-linear dynamic optimization model driven by yield response functions to predict water use and net revenue from farming over 50 years.

2. Estimating the compensated variation, permit price, and penalty for violation while implementing the cap and trade policy over a 50 year planning horizon.

\section{Methods}

A non- linear dynamic optimization model was developed using GAMS (General Algebraic Modeling Systems) under two specific scenarios to evaluate the impact of a water trading policy for irrigation water in the Texas Southern High Plains region. Hale County was chosen as a representative county with cotton, corn, sorghum, and wheat as major crops with substantial acreage to impact the overall irrigation water use in the county (Figure 1).

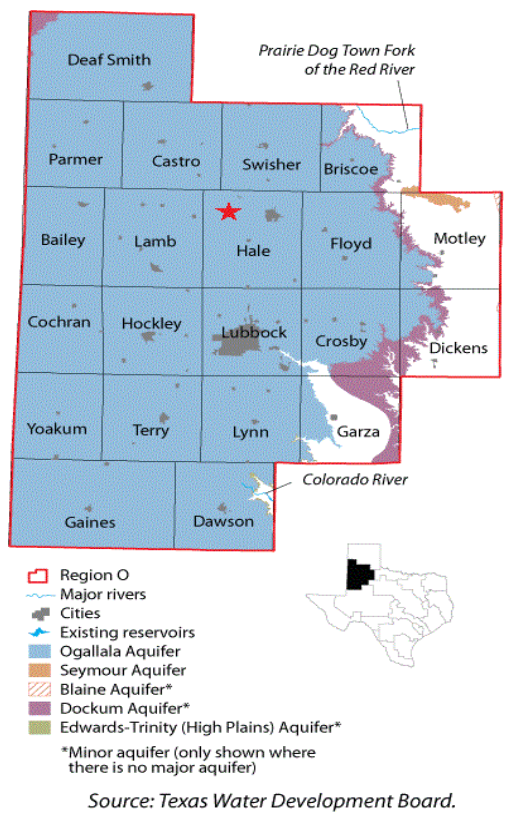

Figure 1. Location of Hale county as the study area

Source: Texas Water Development Board (2011) 


\section{Macrothink}

Approximately $76 \%$ of the acres in the county are irrigated from a total of 322,133 cropped acres. The average saturated thickness of the aquifer is approximately 80 feet. Cotton constitutes for about $60 \%$ of the irrigated acreage, in addition to irrigated corn, irrigated grain sorghum, and irrigated wheat production constituting $18 \%, 11 \%$, and $12 \%$ of the total irrigated acreage respectively (Table1).

Centre-pivot irrigation is assumed as the primary irrigation technology in the study county throughout the planning horizon. The acreage information was obtained from Farm service agency of the USDA. The economic model provides an estimate of water used for irrigation, changes in saturated thickness of the aquifer, and change in net income at the farm level. Crop production functions used in the model were derived from crop models by establishing a quadratic relationship between crop yields and amount of water applied for each crop. Initial aquifer characteristics included in the model are average saturated thickness, depth to water, specific yield, and recharge (Table 1).

Table 1 . County specific parameters (hydrologic and acreage data)

\begin{tabular}{|l|l|l|}
\hline County Land Area (acres) & & 642,976 \\
\hline Amount of Recharge (inches per acre) & & 0.5 \\
\hline Specific Yield & & 0.15 \\
\hline Initial Saturated Thickness (feet) & & 80 \\
\hline Initial Lift (feet) & & 216 \\
\hline Initial Well Yield (gallons per minute) & & 183 \\
\hline Maximum allowable withdrawal (ac-feet) & & 368,704 \\
\hline Initial acres served per well & & 40 \\
\hline Initial Crop Acreages & Irrigated & Dryland \\
\hline Cotton & 148575 & 30060 \\
\hline Corn & 44203 & 0 \\
\hline Sorghum & 26757 & 13900 \\
\hline Wheat & 28704 & 29934 \\
\hline Total & 248239 & 73894 \\
\hline
\end{tabular}

The most recent crop prices, input costs, and the price of natural gas ( $\$ / \mathrm{mcf})$ were used as input to the model, and district budgets from Texas AgriLife Extension Service (Texas AgriLife Extension Service, 2011) were used to calculate costs of production for each crop and output prices averaged over 5 years (Table 2).

Table 2. County specific parameters (commodity prices and production costs)

\begin{tabular}{|l|l|l|l|l|}
\hline Item & Cotton & Corn & Sorghum & Wheat \\
\hline Average price per unit & $\$ 0.55 / \mathrm{lb}$ & $\$ 4.18 / \mathrm{bu}$ & $\$ 6.71 / \mathrm{bu}$ & $\$ 5.55 / \mathrm{bu}$ \\
\hline Variable cost of dryland production & $\$ 165 / \mathrm{ac}$ & $\$ 0.00 / \mathrm{ac}$ & $\$ 83 / \mathrm{ac}$ & $\$ 69 / \mathrm{ac}$ \\
\hline Added variable cost for irrigation & $\$ 105 / \mathrm{ac}$ & $\$ 340 / \mathrm{ac}$ & $\$ 85 / \mathrm{ac}$ & $\$ 90 / \mathrm{ac}$ \\
\hline Harvest cost per unit of production & $\$ 0.13 / \mathrm{lb}$ & $\$ 0.28 / \mathrm{bu}$ & $\$ 0.51 / \mathrm{bu}$ & $\$ 0.46 / \mathrm{bu}$ \\
\hline
\end{tabular}




\subsection{Crop Response Functions}

Non-linear crop production response functions were estimated using CROPMAN, a production-risk management simulation model. County specific inputs to the simulation model are climatic parameters obtained from the closest weather station and soil type. Equations were developed using the quadratic functional form with yield per acre as the dependent variable and irrigation water applied as the independent variable. The established equation for each crop was represented as follows:

$$
Y=\beta_{0}+\beta_{1} X-\beta_{2} X^{2}
$$

Where, $\mathrm{Y}$ represents the yield and $\mathrm{X}$ represents water application rate.

\subsection{Model Specification}

This study was conducted with an objective of finding the most optimal point using a dynamic optimization model to maximize net returns from production of crops over a time horizon of fifty years. The model specification for this study was specifically developed based on a recent study by Tewari et al. (2014) that evaluated the policy option of multi-year water allocation and water use restriction for the Texas High Plains area using a dynamic optimization model.

The objective function is defined as:

$$
\operatorname{Max} N P V=\sum_{\tau=1}^{50} N R_{t}(1+r)^{-\tau}
$$

Where, $N P V$ represents the net present value of net returns; $r$ represents the discount rate; and $N R_{t}$ represents net revenue at time $t$. The bounds of summation for the net revenue are from one to fifty years.

$\mathrm{NR}_{\mathrm{t}}$ is defined as:

$$
\mathrm{NR}_{\mathrm{t}}=\Sigma_{\mathrm{i}} \Sigma_{\mathrm{k}} \Omega_{\mathrm{ikt}}\left\{\mathrm{P}_{\mathrm{i}} \mathrm{Y}_{\mathrm{ikt}}\left[\mathrm{WA}_{\mathrm{ikt}},\left(\mathrm{WP}_{\mathrm{ikt}}\right)\right]-\mathrm{C}_{\mathrm{ik}}\left(\mathrm{WP} \text { ikt }, \mathrm{X}_{\mathrm{t}}, \mathrm{ST}_{\mathrm{t}}\right)\right\}
$$

Where, $i$ represents crops grown; $k$ represents irrigation systems used; $\Omega_{i k t}$ represents the percentage of crop $i$ produced using irrigation system $k$ in time $t, P_{i}$ represents the output price of crop $i, W A_{i k t}$ and $W P_{i k t}$ represent irrigation water application per acre and water pumped per acre, respectively. $Y_{i k t}$ represents the per acre yield production function, $C_{i k t}$ represents the costs per acre, $X_{t}$ represents pump lift at time $t, S T_{t}$ represents the saturated thickness of the aquifer at time $t$.

The main constraints of the model are:

$$
\begin{gathered}
\mathrm{ST}_{\mathrm{t}+1}=\mathrm{ST}_{\mathrm{t}}-\left[\left(\sum_{\mathrm{i}} \Sigma_{\mathrm{k}} \Omega_{\mathrm{ikt}} * \mathrm{WP}_{\mathrm{ikt}}\right)-\mathrm{ARR}\right] \mathrm{PIA} / \mathrm{SY} \\
\mathrm{X}_{\mathrm{t}+1}=\mathrm{X}_{\mathrm{t}}+\left[\left(\Sigma_{\mathrm{i}} \Sigma_{\mathrm{k}} \Omega_{\mathrm{ikt}} * \mathrm{WP}_{\mathrm{ikt}}\right)-\mathrm{ARR}\right] \mathrm{PIA} / \mathrm{SY} \\
\mathrm{GPC}_{\mathrm{t}}=\left(\mathrm{ST}_{\mathrm{t}} / \mathrm{IST}\right)^{2} *(4.42 * \mathrm{WY} / \mathrm{AW})
\end{gathered}
$$




$$
\begin{gathered}
\mathrm{WT}_{\mathrm{t}}=\Sigma_{\mathrm{i}} \Sigma_{\mathrm{k}} \Omega_{\mathrm{ikt}} * \mathrm{WP}_{\mathrm{ikt}} \\
\mathrm{WT}_{\mathrm{t}} \leq \mathrm{GPC}_{\mathrm{t}} \\
\mathrm{PC}_{\mathrm{ikt}}=\left\{\left[\mathrm{EF}\left(\mathrm{X}_{\mathrm{t}}+2.31 * \mathrm{PSI}\right) \mathrm{EP}\right] / \mathrm{EFF}\right\}^{*} \mathrm{WP}_{\mathrm{ikt}} \\
\mathrm{C}_{\mathrm{ikt}}=\mathrm{VPC}_{\mathrm{ik}}+\mathrm{PC}_{\mathrm{ikt}}+\mathrm{HC}_{\mathrm{ikt}}+\mathrm{MC}_{\mathrm{k}}+\mathrm{DP}_{\mathrm{k}}+\mathrm{LC}_{\mathrm{k}} \\
\Sigma_{\mathrm{i}} \Sigma_{\mathrm{k}} \Omega_{\mathrm{ikt}} \leq 1 \text { for all } \mathrm{t} \\
\Omega_{\mathrm{ikt}} \geq(2 / 3) \Omega_{\mathrm{ik}(\mathrm{t}-1),} \\
\Omega_{\mathrm{ikt}} \geq 0
\end{gathered}
$$

Equations (4) and (5) specify the two state variables, saturated thickness and pumping lift, $S T_{t}$ and $X_{t}$ respectively where $A R R$ represents the annual recharge rate in feet, PIA represents the percentage of irrigated acres, and $S Y$ represents the specific yield of the aquifer. In equation (6), GPC represents gross pumping capacity, IST represents the initial saturated thickness of the aquifer in year one of the planning horizon, and $W Y$ represents the average initial well yield for the county in year one. Constraints (7) and (8) are the water application and water pumping capacity constraints, respectively. Equation (7) represents the total amount of water pumped per acre, $W T_{t}$, as the sum of water pumped on each crop. Constraint (8) requires $W T_{t}$ to be less than or equal to GPC. Equations (9) and (10) represent the cost functions in the model. In Equation (9), $P C_{i k t}$ represents the cost of pumping, $E F$ represents the energy use factor for electricity, $E P$ is the price of energy, $E F F$ represents pump efficiency, and 2.31 feet is the height of a column of water that will exert a pressure of 1 pound per square inch. Equation (10) expresses the cost of production, $C_{i k t}$, in terms of $V P C_{i k}$, the variable cost of production per acre; $H C_{i k t}$, the harvest cost per acre; $M C_{k}$, the irrigation system maintenance cost per acre; $D P_{k}$, the per acre depreciation of the irrigation system per year; and $L C_{k}$, the cost of labor per acre for the irrigation system. Equation (11) limits the fractional sum of all acres of crops $i$ produced by irrigation systems $k$ for time period $t$ to be less than or equal to one. Equation (12) is a constraint placed in the model to limit the annual shift to a $33.3 \%$ change from the previous year's acreage to constrain the model from predicting rapid shifts towards dryland cropping. Equation (13) is a non-negativity constraint to assure all decision variables in the model take on positive values.

A status-quo scenario (unrestricted) was compared with a 50/50 management scenario (restricted) to estimate the changes in saturated thickness, water applied per cropland acre, and per acre net revenue from farming over a 50 year planning horizon. The difference in the net revenue between the two scenarios over a stipulated planning horizon provided a measure of the compensated variation in \$/acre which reflects the willingness to pay on behalf of the producers for water units available for trade, when a 50/50 management plan is implemented.

The change in marginal pumping cost for irrigation water was also calculated to derive the 


\section{Ml Macrothink}

price of permit and penalty for violation, when implementing the cap and trade policy. The price of permit is calculated as the difference between the compensated variation and the marginal pumping cost in \$/ac-in. The penalty of violation also in \$/ac-in is calculated as the sum total of the compensated variation and the marginal pumping cost. The change in consumer surplus is simply the difference in the net returns per acre between the restricted and unrestricted scenarios for each year. In addition, a comparison was drawn for different levels of saturated thickness to observe the variation in price of permit, penalty for violation, as well as change in consumer surplus with variations in initial saturated thickness levels, when implementing a trading scenario coupled with water use restriction.

\section{Results and Discussion}

Saturated thickness levels declined under both the scenarios, with the unrestricted scenario showing a higher decline from $80 \mathrm{ft}$ to $22 \mathrm{ft}$, as compared to the 50/50 scenario where the saturated thickness declined from $80 \mathrm{ft}$ to $40 \mathrm{ft}$ (Figure 2).

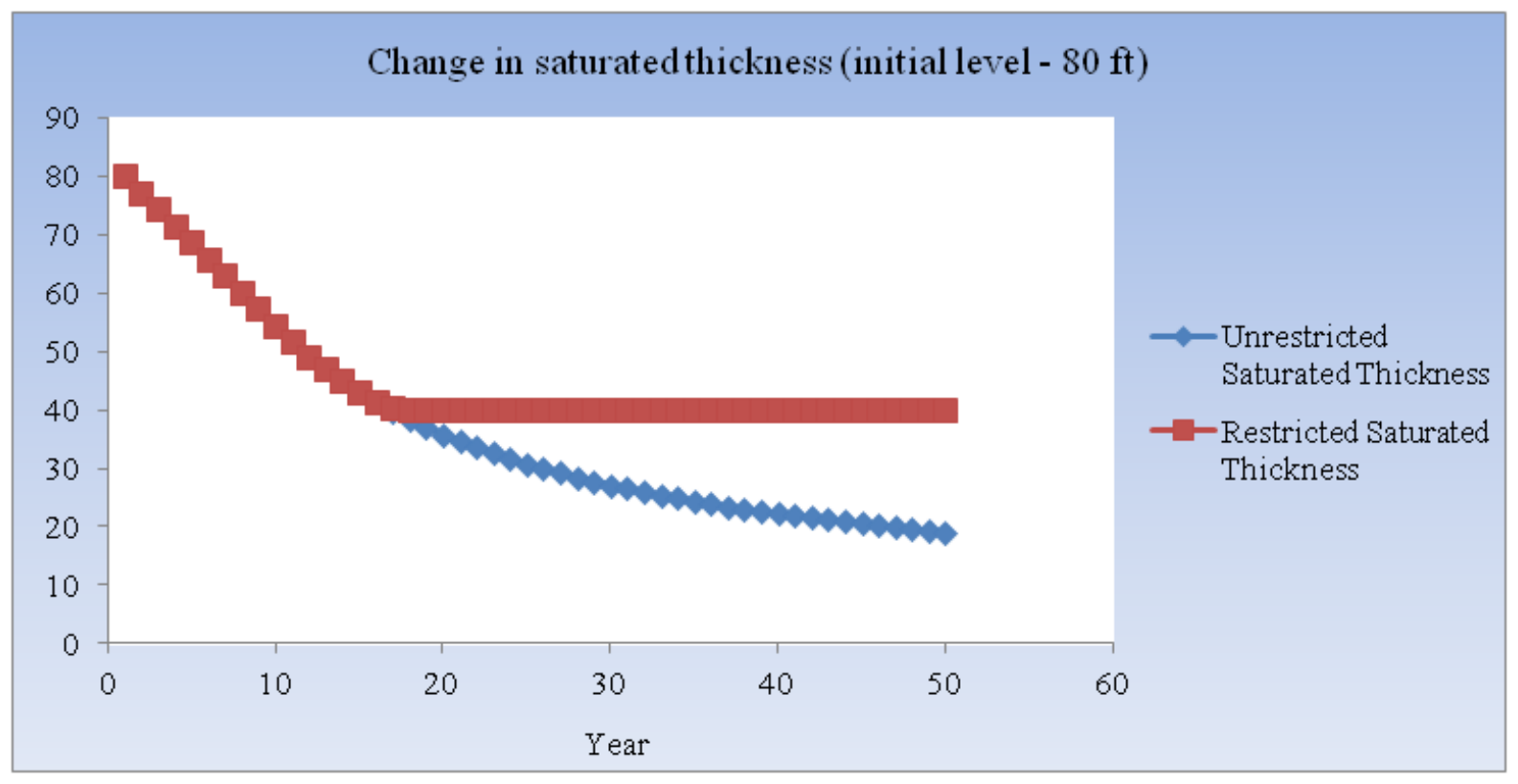

Figure 2. Change in saturated thickness levels over the planning horizon (initial level - $80 \mathrm{ft}$ )

Due to the restriction on water availability under the 50/50 management goal, the net revenue per acre showed a higher decline when compared to the unrestricted scenario on account of reduction in irrigated production over the planning horizon. The net present values per acre under the restricted and unrestricted scenarios were $\$ 3,090$ and $\$ 3,557$ respectively (Figure $3)$.

The water use per acre was also impacted in a similar manner with a higher decline in water applied per cropland acre under the restricted scenario, as compared to the unrestricted scenario. An interesting observation for the $10^{\text {th }}$ year of the planning horizon under the restricted scenario was the sharp decline in net revenue per acre. A possible explanation could be that at this point water became a limiting factor because of declining levels of saturated thickness, and that is when the differences under the two scenarios became more evident. 


\section{Macrothink}

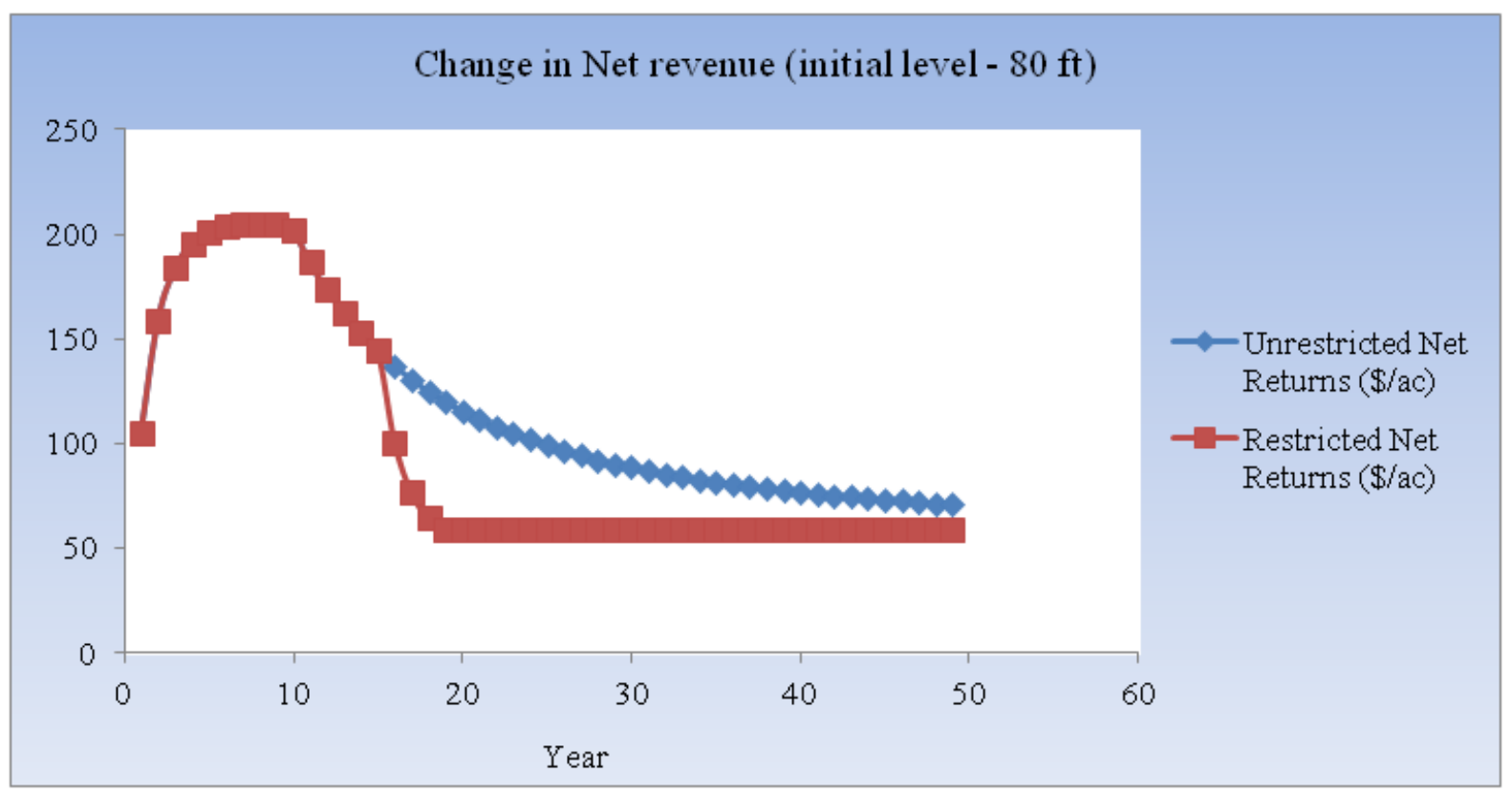

Figure 3. Change in net revenue over the planning horizon (initial level - $80 \mathrm{ft}$ )

Figure 4 depicts the changes in consumer surplus, price of permit, and penalty of violation in the event of a 50/50 management plan being implemented, and a water trading policy introduced. Until year 10, the producers have no incentive to enroll in a water trading policy because at this point water availability is not a constraint in irrigated production. Soon after, as water becomes limiting the market for water trading opens up and continues to function as long as it is viable to pump water for irrigation.

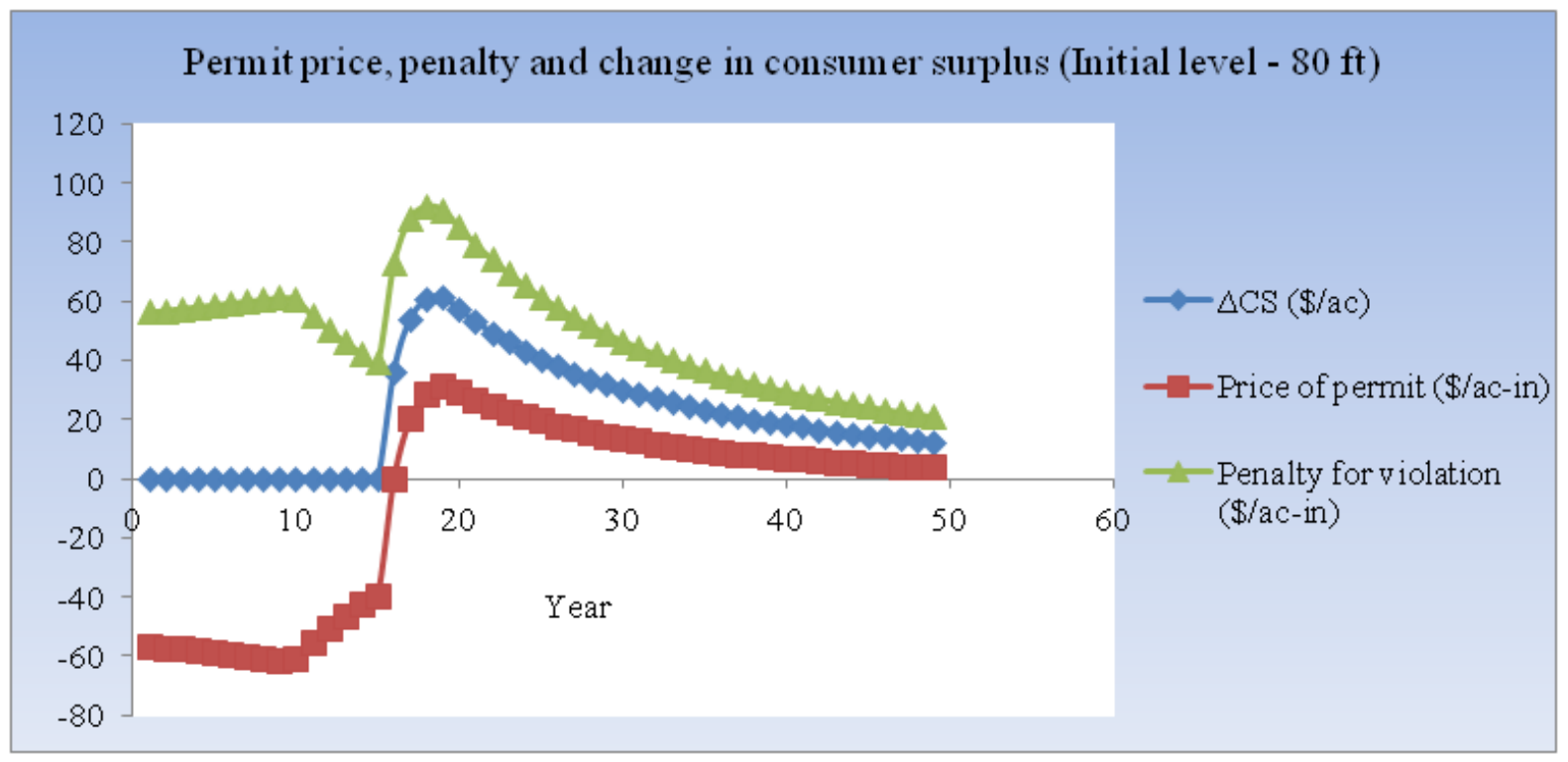

Figure 4. Change in permit price, penalty and change in consumer surplus over the planning horizon (initial level - $80 \mathrm{ft}$ )

Table 3 depicts the comparison of permit price, penalty for violation, and change in consumer surplus at varying levels of initial saturated thickness. It was noted that under the restricted 
scenario the water use behavior does not change for beginning $20 \%$ of the initial saturated thickness at various levels. When comparing the saturated thickness level changes under the two scenarios, the decline is highest for $200 \mathrm{ft}$ initial saturated thickness, followed by $60 \mathrm{ft}$ initial low saturated thickness. For $80 \mathrm{ft}, 100 \mathrm{ft}$, and $200 \mathrm{ft}$ initial levels, the difference in saturated thickness levels between the restricted and unrestricted scenarios was lower than that found for $200 \mathrm{ft}$ and $60 \mathrm{ft}$. This implies that the restriction policy is not very effective in conserving water at the end of the planning horizon where there the saturated thickness levels are as deep as $200 \mathrm{ft}$.

Table 3. Comparison of permit price and penalty for violation at various levels of saturated thickness

\begin{tabular}{|l|c|c|c|c|c|}
\hline Initial saturated thickness & $60 f t$ & $80 \mathrm{ft}$ & $100 \mathrm{ft}$ & $150 \mathrm{ft}$ & $200 \mathrm{ft}$ \\
\hline $\begin{array}{l}\text { Difference in Saturated thickness over 50 years (restricted v/s } \\
\text { unrestricted) }\end{array}$ & 18.08 & 20.89 & 22.22 & 20 & 11.50 \\
\hline Remaining saturated thickness in 50 years (unrestricted scenario) & 11.92 & 19.10 & 27.78 & 54.99 & 88.47 \\
\hline $\begin{array}{l}\text { Starting year for positive change in consumer surplus } \\
\text { Max } \Delta \text { consumer surplus (\$/ac) } \\
\text { (occurs at year) }\end{array}$ & 10 & 15 & 19 & 29 & 20 \\
\hline $\begin{array}{l}\text { Max price (\$/ac-inch) } \\
\text { Max penalty(\$/ac-inch) }\end{array}$ & $\begin{array}{c}59.21 \\
(14)\end{array}$ & $\begin{array}{c}61.33 \\
(19)\end{array}$ & $\begin{array}{c}62.54 \\
(23)\end{array}$ & $\begin{array}{c}62.80 \\
(33)\end{array}$ & $\begin{array}{c}61.47 \\
(43)\end{array}$ \\
\hline
\end{tabular}

Further, for lower saturated thickness levels the water use starts to decline in the first decade of policy implementation in comparison to the $200 \mathrm{ft}$ level where the effect is more pronounced during the last decade of the planning horizon. When trading of water among agricultural producers is permitted, the maximum price of water would be recorded for initial low saturated thickness levels as compared to high initial saturated thickness levels. Conversely, the penalty for overutilization of water is higher for greater initial saturated thickness levels in comparison to shallow initial saturated thickness levels. In the beginning years of restriction policy being implemented, mostly irrigated cotton is produced, which does not generate very high returns at the base prices assumed in the model. Other crops produced in the beginning period are irrigated corn, irrigated sorghum, irrigated wheat, dryland cotton, dryland sorghum and dryland wheat. Moving further into the planning horizon production of irrigated corn and dryland wheat increase largely thereby resulting in a higher net revenue. In the latter years of the planning horizon, dryland wheat occupies the maximum acreage due to decreased water availability. This effect on the crop mix is the same across all levels of initial saturated thickness.

\section{Conclusion}

This study evaluated the possibility of implementing a water trading scenario in conjunction with a water use restriction policy in the Texas Southern High Plains. The results suggested 
that the decision of producers to engage in water trading introduced under a restricted 50/50 management plan will be impacted by initial water levels in the aquifer, as well as the viability of pumping irrigation water when moving further into the planning horizon. The highest change in consumer surplus, price of permit, as well as the penalty of violation is observed in the periods where water becomes limiting and the overall supply of available water in the study area declines. The results also suggest that the restricted and unrestricted scenarios do not present substantial differences in water use until water level becomes limiting. Comparing the results for varying levels of initial saturated thickness indicated that the impact of water withdrawals and trading of water critically depends upon initial water levels in the aquifer, and subsequently the viability of pumping irrigation water further into the planning horizon. Declining levels of saturated thickness lead producers to switch from irrigated to dryland crop production to remain economically viable, and this points out the insignificant impact of imposing a water use restriction into the latter years of the planning horizon. In conclusion, while management policies such as restricting water use and permitting water trading will have a definitive impact on the crop-mix, farm income, and the regional economy, they could still serve as useful tools to promote long term conservation of groundwater resources in the region.

\section{References}

Amosson, S., L. Almas, B. Golden, B. Guerrero, J. Johnson, R. Taylor, \& E. Wheeler-Cook. (2009). Economic Impacts of Selected Water Conservation Policies in the Ogallala Aquifer. Ogallala Aquifer Project. Jan 2009.

Chopra, K., R. Leemans, P. Kumar, \& H. Simons, editors. (2005). Ecosystems and human well-being: policy responses. 3. Island Press, Washington, D.C., USA.

Colby, B. G. (2000). Cap-and-Trade Policy Challenges: A Tale of Three Markets. Land Economics, University of Wisconsin Press, Madison, WI, 76(4): 638-658. http://dx.doi.org/10.2307/3146957

Kolstad, C. D. (2000). Environmental Economics. Oxford University Press, New York, New York.

Mace, R.E., R. Petrossian, R. Bradley, WF Mullican III, and L. Christian. (2008). A Streetcar named Desired Future Conditions: The New Groundwater Availability for Texas (Revised). Texas Water Development Board. [Online] Available: http://www.twdb.state.tx.us/groundwater/docs/Streetcar.pdf (April 21, 2015).

Selman, Mindy., Branosky, Evan., and Jones, Cy. (2009). Water Quality Trading Programs: An International Overview. World resources instate: Water quality Trading. [Online] Available:

http://www.wri.org/sites/default/files/pdf/water_trading_quality_programs_international_over view.pdf_(April 21, 2015).

Postel, S. (2012). Texas Water District Acts to Slow Depletion of the Ogallala Aquifer. National Geographic's Freshwater Initiative. [Online] Available: 


\section{Macrothink}

http://newswatch.nationalgeographic.com/2012/02/07/texas-water-district-acts-to-slow-deplet ion-of-the-ogallala-aquifer/ (April 21, 2015).

Tewari, R., L. K. Almas, J. Johnson, B. Golden, S. Amosson, \& B.L. Guerrero (2014). Multi-Year Water Allocation: An Economic Approach towards Future planning and Management of Declining Groundwater Resources in the Texas Panhandle. Texas Water Journal. Vol 5(1), 2014. [Online] Available:

https://journals.tdl.org/twj/index.php/twj/article/view/6390(April 21, 2015).

Texas AgriLife Extension Service. (2011). 2012 Texas Crop and Livestock Enterprise Budgets. District 2 - South Plains. Extension Agricultural Economics. [Online] Available: http://agecoext.tamu.edu/resources/crop-livestock-budgets/budgets-by-extension-district/distr ict-2-south-plains/ (April 21, 2015).

Thompson, C. L., R. J. Supalla, D. L. Martin, \& B. P. McMullen. (2009). Evidence Supporting Cap and Trade as a Groundwater Policy Option for Reducing Irrigation Consumptive Use, Journal of the American Water Resources Association, 45(6), 1508-1518. http://dx.doi.org/10.1111/j.1752-1688.2009.00384.x

Tietenberg, T. H. (1990). Economic Instruments for Environmental Regulation. Oxford Review of Economic Policy, 6(1), 17-33. http://dx.doi.org/10.1093/oxrep/6.1.17

\section{Copyright Disclaimer}

Copyright for this article is retained by the author(s), with first publication rights granted to the journal.

This is an open-access article distributed under the terms and conditions of the Creative Commons Attribution license (http://creativecommons.org/licenses/by/3.0/). 